\title{
Ulcerative colitis and Crohn's disease: is Mycobacterium avium subspecies paratuberculosis the common villain?
}

\author{
Ellen S Pierce
}

\begin{abstract}
Mycobacterium avium, subspecies paratuberculosis (MAP) causes a chronic disease of the intestines in dairy cows and a wide range of other animals, including nonhuman primates, called Johne's ("Yo-knee's") disease. MAP has been consistently identified by a variety of techniques in humans with Crohn's disease. The research investigating the presence of MAP in patients with Crohn's disease has often identified MAP in the "negative" ulcerative colitis controls as well, suggesting that ulcerative colitis is also caused by MAP. Like other infectious diseases, dose, route of infection, age, sex and genes influence whether an individual infected with MAP develops ulcerative colitis or Crohn's disease. The apparently opposite role of smoking, increasing the risk of Crohn's disease while decreasing the risk of ulcerative colitis, is explained by a more careful review of the literature that reveals smoking causes an increase in both diseases but switches the phenotype from ulcerative colitis to Crohn's disease. MAP as the sole etiologic agent of both ulcerative colitis and Crohn's disease explains their common epidemiology, geographic distribution and familial and sporadic clusters, providing a unified hypothesis for the prevention and cure of the no longer "idiopathic" inflammatory bowel diseases.
\end{abstract}

\section{Introduction}

Ulcerative colitis and Crohn's disease are chronic diseases of the gastrointestinal tract that together are usually referred to as idiopathic inflammatory bowel disease (IIBD). The word "idiopathic" means "of unknown cause," but the currently accepted theory of the cause of these diseases postulates a nebulous combination of immune dysfunction, "dysbiosis," [1] and otherwise normal constituents of the commensal extracellular luminal gut bacteria [2] leaking through an abnormally permeable mucosal layer [3] in genetically predisposed individuals [4].

The main alternative theory of Crohn's disease causation is infection with a facultative intracellular bacterium, Mycobacterium avium, subspecies paratuberculosis (MAP) [5-8]. MAP causes a chronic disease of the intestines $[9,10]$ in a variety of animals [11-16], including nonhuman primates [17], that shares some histologic (i.e., microscopic) similarities to the changes found in Crohn's disease.

Correspondence: ellenpiercemd@gmail.com Spokane Valley, Washington, USA
This commentary proposes that ulcerative colitis is also caused by MAP. The epidemiology, geographic distribution [18] and clusters (both sporadic and familial) of ulcerative colitis and Crohn's disease are consistent with MAP as the single etiologic agent of both diseases. Like other infectious diseases [19], a variety of factors including dose, route of infection, age, sex and genes influences whether an individual infected with MAP develops ulcerative colitis or Crohn's disease.

\section{Discussion}

Crohn's disease in unrelated individuals is an infectious disease; it is caused by a microorganism transmitted in water by the fecal-oral route

Let's begin in the middle of the story. What causes Crohn's disease, and how are ulcerative colitis and Crohn's disease related to one another? In 2001, Van Kruiningen and Freda [20] published their study of a "clustering of Crohn's disease in Mankato, Minnesota," that described 7 unrelated individuals with Crohn's disease in the city of Mankato, all members of the Mankato West High School class of 1980. The circumstances of the development of their Crohn's disease led

\section{() Biomed Central}


the authors of this study to conclude that these cases of Crohn's disease were caused by

environmental transmission, transmission of a modestly contagious microbial agent via a fecal-oral route...related to bacterial surface water pollution... (Crohn's disease) may have been contracted via bathing or swimming in contaminated waters, via contamination of fresh vegetable crops, or via surface water contamination of wells during flooding [20].

Fecal-oral transmission means that a microorganism present in the feces of an animal contaminates the food or water that a person swallows. This one study concluded that Crohn's disease in unrelated individuals is an infectious disease; that is, it is caused by a microorganism, found in animal feces, that contaminates water.

\section{Crohn's disease in families, in genetically related individuals, is also an infectious disease}

Genetically related individuals, families who have several members with Crohn's disease, also develop Crohn's disease because they are infected with the causative microorganism. In 1993, Van Kruiningen and colleagues published a "Study of Crohn's disease in Two French Families." [21] In the first family, the father developed Crohn's disease in 1970. In 1974, within several months of each other, 2 of their 4 children developed Crohn's disease. In 1982 and 1983, the other two children developed Crohn's disease. Finally, in 1988, the mother developed Crohn's disease. In the second family, 7 of the 11 children developed Crohn's disease, again in a pattern (first 4 of the children within 10 months of each other, then 6 years later another child, then 6 years after that, 2 more siblings) that led the authors of this study to conclude that "an enteric pathogen" caused these families to develop Crohn's disease:

The uniformity of ileal and cecal disease in family 1 is akin to that which might be expected had a uniform dose of an enteric pathogen been given to a genetically uniform group of experimental subjects, e.g., a litter of mice or piglets [21].

The conclusions that can be drawn from these two studies are that genetically unrelated people develop Crohn's disease because they have been infected with the causative microorganism, and genetically related people also develop Crohn's disease because they have been infected with the causative microorganism.
Sporadic Crohn's disease, Crohn's disease in genetically unrelated individuals, is the same disease as familial Crohn's disease, Crohn's disease in genetically related individuals

We have thus far determined that Crohn's disease, whether in related or unrelated individuals, is an infectious disease, meaning that people develop Crohn's disease because they have been infected with the causative microorganism. But is sporadic Crohn's disease the same kind of disease as familial Crohn's disease? Is the infectious microorganism that causes unrelated people to develop Crohn's disease the same microorganism that causes families to develop Crohn's disease? Studies of families with Crohn's disease have concluded that there is no essential difference between the pathology of Crohn's disease in families with the disease and in unrelated individuals with the disease. Since there are no essential differences in the pathology of sporadic versus familial Crohn's disease [22-25], the organism that causes them must also be the same.

\section{How is ulcerative colitis related to Crohn's disease? The same infectious microorganism that causes Crohn's disease sometimes causes ulcerative colitis instead}

The studies of sporadic and familial clusters of Crohn's disease conclude that Crohn's disease is caused by an infectious microorganism, and that, whether sporadic or familial, Crohn's disease is the same disease. How, then, is ulcerative colitis related to Crohn's disease? Let's return to those "two French families" [21], where a total of 13 individuals developed Crohn's disease. In the second of these families, in which 7 of the 11 children developed Crohn's disease, one affected child "presented initially with diffuse mucosal colitis and may have had ulcerative colitis as well as Crohn's disease." [21] The same "enteric pathogen," the same "infectious microorganism" that caused the 13 individuals in these two families to develop Crohn's disease caused one of those 13 individuals to also develop ulcerative colitis.

The same microorganism that causes the rare patient to develop both Crohn's disease and ulcerative colitis [26-29] usually causes some individuals to develop one disease or the other. Numerous studies of "mixed" families [30-34], where some individuals in a family develop ulcerative colitis and others develop Crohn's disease, are usually used to illustrate the idea that Crohn's disease and ulcerative colitis are genetic diseases, that some combination of genes causes both diseases. If, however, Crohn's disease is an infectious disease, these same studies of "mixed" families can just as easily illustrate the idea that if an infectious microorganism causes Crohn's disease, that same infectious microorganism sometimes causes ulcerative colitis instead [30-34]. 
If the same microorganism causes some genetically related individuals to get ulcerative colitis and others to get Crohn's disease, and if sporadic Crohn's disease (Crohn's disease in genetically unrelated individuals) is the same disease as familial Crohn's disease (Crohn's disease in genetically related individuals), then sometimes unrelated people will get ulcerative colitis rather than Crohn's disease when infected with the same microorganism. This is illustrated by the first of the two French families, where both the (genetically unrelated) mother and the father developed Crohn's disease [21], as well as the studies of unrelated spouses who both develop IBD: in some cases both spouses develop Crohn's disease [35-37], in some cases one spouse develops Crohn's disease and the other ulcerative colitis [38-40], and in some cases both spouses develop ulcerative colitis [38-41].

Unmarried and unrelated individuals living together also sometimes develop ulcerative colitis rather than Crohn's disease when infected with the same microorganism. In one of these nonfamilial or sporadic clusters, Aisenberg and Janowitz [42] describe 3 friends who shared living quarters in college. Several years after they left school, 2 of the friends developed Crohn's disease, and 1 developed ulcerative colitis.

The idea that ulcerative colitis and Crohn's disease have the same etiology is supported by consideration of the general epidemiology of these two disorders:

The significant linear regression between the incidence of Crohn's disease and ulcerative colitis from different countries and a similar relationship between the mortalities from both diseases could mean that the two diseases share a common factor in their etiology [43].

All studies (of the populations affected by IBD) thus far have failed to show that the population which develops Crohn's disease differs in any important feature from that which develops ulcerative colitis [44]. Crohn's disease and ulcerative colitis have similar demographic features. They...occur in the same places and at similar times. Where Crohn's disease is common, so is ulcerative colitis [45].

\section{Which specific infectious microorganism is found in patients with Crohn's disease ...and ulcerative colitis? MAP}

MAP is an organism found in animal feces. It infects and causes clinical disease, called Johne's ('Yo-knees') disease, in a wide variety of animal species. Several meta-analyses and reviews of the literature have concluded that the MAP organism is consistently associated with Crohn's disease [46-48]:

...the MAP Crohn's disease phenomenon has fulfilled at least four (strength of association, consistency of effect, temporality and biological plausibility) of the six epidemiological causal criteria outlined by Hill... the current epidemiological evidence strongly supports the conjecture that Crohn's disease is caused by MAP [46].

There is an association between MAP and (Crohn's disease), across many sites, by many investigators, and controlling for a number of factors [48].

...our meta-analysis showed an association between MAP and Crohn's disease that is robust and specific [49].

The studies attempting to identify the MAP organism in Crohn's disease by a variety of techniques have often used ulcerative colitis as the "negative" control, under the assumption that MAP may cause Crohn's disease, but not ulcerative colitis $[47,48]$. When MAP is identified in both Crohn's disease and ulcerative colitis, researchers conclude that MAP causes neither disease. If, however, the current body of research is looked at from the point of view that MAP might cause ulcerative colitis as well as Crohn's disease, there is evidence to support this alternative position.

Like the organism that causes tuberculosis, Mycobacterium tuberculosis, that infects one-third of the world's population [50] as estimated by positive tuberculin skin testing [19], serum antibodies to various MAP antigens are found in a third of the population in countries with a high incidence of ulcerative colitis and Crohn's disease [51] and in patients with both diseases [51-53]. MAP can be identified by IS900 PCR (polymerase chain reaction) in the tissues [54-58] and cultured from the bloodstreams [59] of patients with ulcerative colitis as well as patients with Crohn's disease.

For a pathologist such as the author, the most convincing evidence of causation is direct visualization: can the organism be seen under the (light) microscope? The evidence from direct visualization is actually the strongest support for the idea that MAP causes ulcerative colitis as well as Crohn's disease: MAP can be directly visualized in patients with both diseases $[60,61]$. In the single study that directly visualized MAC (Mycobacterium avium complex) organisms (of which MAP is one) in almost $60 \%$ of Crohn's tissues using traditional acid fast stains [60], MAC organisms were also seen in $40 \%$ (2 of the 5) of the ulcerative colitis tissues. However, these researchers went so far as to reclassify their ulcerative colitis patients as having Crohn's disease, rather than concluding that MAC organisms can be 
directly visualized in both ulcerative colitis and Crohn's tissues:

...the observation of positive results in a few controls requires further clarification ...2 of the 5 control subjects with positive results had ileal disease but an assigned diagnosis of UC (ulcerative colitis); if these patients instead were classified as Crohn's disease, the Odds Ratio would increase from 8.6 to 17.1 [60].

If the data are accepted that MAP is present in both ulcerative colitis and Crohn's disease tissues, the conclusion can be drawn that MAP causes both diseases. Why, then, do some patients develop ulcerative colitis rather than Crohn's disease when infected with the same microorganism?

\section{When infected with MAP, why do some individuals develop ulcerative colitis rather than Crohn's disease? The usual influences of dose, route, age, sex and genes on the clinical expression of an infection}

Like any other pathogenic (disease-causing) microorganism, a variety of factors influences the phenotype, the clinical expression of MAP infection; whether an individual develops one disease caused by MAP or another. Not everyone infected by a pathogenic microorganism develops a disease caused by that organism. "Infection" means the "multiplication of the organism in or on the host." [19] In contrast, "disease represents a clinically apparent response of the host to infection." [19] A review of the literature suggests that five factors influence whether an individual develops ulcerative colitis or Crohn's disease when infected with MAP:

1) The dose of the MAP organism, or how many organisms infect an individual. For a given age, a small dose of MAP causes ulcerative colitis, while a large dose of MAP causes Crohn's disease.

2) The route of infection. The literature suggests that routes of infection that increase the concentration of MAP increase the risk of developing Crohn's disease rather than ulcerative colitis. The two routes of infection that potentially concentrate MAP are aerosolized water from rivers and other bodies of water contaminated with MAP, and MAP present in hyperosmolar milk rather than hypoosmolar water.

3) The age at which an individual is infected. It takes a smaller dose of MAP to cause either ulcerative colitis or Crohn's disease in a child as compared to an adult.

4) Specific genes that control how an individual processes intracellular bacteria, and specifically mycobacteria. Individuals with these genes have a slighter greater tendency to develop Crohn's disease rather than ulcerative colitis, when infected with the MAP organism.

5) Whether an individual is male or female. Infant males and adult females seem to have a greater chance of developing Crohn's disease rather than ulcerative colitis when infected with MAP.

The interactive influences of age and dose: when infected with a small dose of MAP, adults develop ulcerative colitis relatively soon after being infected, while children develop Crohn's disease after a long latency period

An examination of another family with both diseases suggests why some people get ulcerative colitis and others get Crohn's disease when infected with the same microorganism. This family had been living in a section of Germany with water that "was poorly controlled hygienically." [62] The mother, the adult, developed ulcerative colitis only 6 months after living in the area. Her two children developed Crohn's disease, one 4 years after living in the area and the other 5 years after.

This pattern of development, first of ulcerative colitis, then several years later of Crohn's disease, is illustrated occasionally at the individual level in patients who first develop ulcerative colitis, and then approximately 10 years later develop Crohn's disease [27]. More commonly, in high incidence countries, the incidence of ulcerative colitis first increases, followed several years later by Crohn's disease [63-65]. At the population level, immigrants from low to high prevalence IBD countries first develop ulcerative colitis [66], then again after approximately a decade begin developing Crohn's disease [67-70]. Adult and child immigrants from low to high prevalence IBD countries are infected at the same time, but the adults develop ulcerative colitis relatively soon after being infected, while the children develop Crohn's disease approximately 5 to 15 years after infection. The latency period between infection with MAP and the development of Crohn's disease is consistent with the literature on Johne's disease, where animals are infected as young animals but don't develop the clinical disease until they are adults [71].

As countries become westernized, meaning specifically the introduction of MAP-contaminated beef and dairy foods and the corresponding environmental pollution by MAP-infested beef and dairy cattle feces, their populations first develop ulcerative colitis and then again after a delay of several years develop Crohn's disease:

As societies become more "westernized" or industrialized...ulcerative colitis emerges, but the incidence of Crohn's disease remains low. Over time, Crohn's disease emerges, and its incidence ultimately matches that of ulcerative colitis [69]. 
The ratio of CD (Crohn's disease) to UC (ulcerative colitis) has changed over the past 50 years, with early reports in the mid- $20^{\text {th }}$ century describing a predominance of UC cases in the United States and Western Europe. A gradual rise in CD cases in the 1960's through the 1990's resulted in CD incidence surpassing UC incidence in most westernized countries. Studies from Japan recapitulate the US experience, with a predominance of UC cases early and a rise in CD approximately 1 decade later [67].

For a given age, infection with a small dose of MAP causes ulcerative colitis, while infection with a large dose of MAP causes Crohn's disease

At the microscopic level, a "small number" of organisms means 1 or 2 microorganisms within a single cell, requiring x1000 magnification to be seen under the light microscope [60], while a "large number" of organisms means a group of 3 or more organisms within a single cell, that can be identified at a magnification of $x 400$ [72]. At the macroscopic level, however, a small number of organisms, a small "bacterial burden" or a small "dose" of MAP refers to numbers of organisms on the order of $10^{7}, 10$ million organisms or less, while a large bacterial burden refers to doses on the order of $10^{8}$ or 100 million organisms or more.

In a recent study, Smith and colleagues [73] demonstrated that patients with Crohn's disease have trouble clearing large numbers of subcutaneously injected Escherichia coli organisms from their tissues:

Bacterial clearance was dramatically different between the two ( $\mathrm{HC}$ or healthy control and CD or Crohn's disease) groups. In HC subjects, clearance rates were relatively stable between $10^{5}$ and $3 \times 10^{7}$ organisms and actually increased at the highest dose, whereas in CD, although it was normal at $10^{5}$ and $10^{6}$, there was a dramatic and highly significant drop in clearance at and above $10^{7}$ bacteria [73].

These researchers concluded that Crohn's patients can clear small doses of bacteria from their tissues, but not large doses:

Most acute infections originate from a small number of inoculating organisms, which even the dampened immunity in CD appears able to control. Our findings of the relationship between bacterial dose and clearance are important in this respect because they demonstrate that $C D$ patients can deal efficiently with small numbers of organisms in the tissues, but that the clearance mechanisms are overwhelmed by a large bolus of bacteria [73].

These researchers discuss the idea that the ileum and proximal colon are exposed to large numbers of luminal bacteria, specifically in the range of $10^{8}$ in the ileum and $10^{11}$ in the colon, and speculate that Crohn's patients might have trouble handling these massive doses of normal luminal bacteria [73]. However, an alternative explanation is that patients with Crohn's disease do not have trouble handling massive loads of normal luminal bacteria, but do have trouble handling large doses of MAP.

MAP is one of the subspecies of the Mycobacterium avium complex (MAC) group of microorganisms [74]. Normal water treatment processes such as filtration and chlorination amplify rather than eliminate MAC organisms by killing off their competitors [75,76]. In addition, MAC organisms grow on tap water pipes [77], in biofilms [78] and on plastic water bottles [79]. MAP has been identified in drinking water in the United States $[80,81]$ and elsewhere [82]. It is estimated that MAC organisms may be present in drinking water on the level of up to 700,000 or $7 \times 10^{5}$ organisms per liter of water [77]. If an individual drinks 2 liters of water a day, it will take just over 2 months to ingest $10^{8}$ or "massive numbers" of MAP organisms.

Once the level of MAP organisms in drinking water regularly reaches hundreds of thousands of organisms per liter, the chances of ingesting such large doses of MAP reaches a saturation level [43] and the rate of Crohn's disease and ulcerative colitis in a population stabilizes, with the chances of ingesting large doses of MAP generally being greater than ingesting small doses. Therefore, in populations with a high prevalence of IBD, there is usually a higher prevalence of Crohn's disease than ulcerative colitis $[67,83-85]$.

As discussed above, when infected with a small dose of MAP, an adult develops ulcerative colitis relatively soon after infection, while a child develops Crohn's disease many years after infection. As the level of MAP organisms increases in the environment, including drinking water, a child has a greater chance of getting infected with a large dose. The author proposes that children infected with a large dose of MAP develop Crohn's disease with a shorter latency period between infection and clinical disease, including newborn infants [86].

In the study above [73], ulcerative colitis patients were able to clear large doses of E. coli, unlike the Crohn's patients. The author believes that ulcerative colitis patients have a more aggressive response to any dose of MAP, whether small or large, whereas Crohn's patients can handle small doses of MAP but not large ones. So patients develop ulcerative colitis even when infected with small doses of MAP. 
The two routes of MAP infection: manure and milk

MAP is excreted in an infected animal's feces and secreted in its milk. There are, therefore, 2 different routes of infecting humans with MAP: fecal-oral transmission via contaminated water, and consumption of contaminated milk or products made from contaminated milk. A careful examination of the literature reveals that routes of infection that result in concentrating MAP result in a greater likelihood of developing Crohn's disease rather than ulcerative colitis.

The first route of transmission of MAP to humans is fecal-oral transmission. "Fecal-oral spread is an important means of transmission of a variety of bacterial, viral and parasitic diseases...It may involve...finger-to-mouth spread, the use of night soil as fertilizer, or fecal contamination of food or water" [19]. The reported clusters of Crohn's disease associated with fecal-oral transmission have involved the use of manure as fertilizer $[21,87]$ and possible fecal contamination of treated (tap) water [88], untreated (well) water [89] and surface water used for recreation [20]. Direct contact with dairy cattle feces has also been associated with an increased risk of ulcerative colitis in adult male farm workers [90].

MAP causes chronic intestinal disease in animals whether ingested, injected subcutaneously or intravenously, or inhaled [7], and aerosolization from possibly MAP-contaminated bodies of water, particularly rivers, is associated with an increased risk of Crohn's disease as compared to ulcerative colitis. There is a particularly high incidence of Crohn's disease in cities with rivers running through them, as exemplified by the author's home of Spokane, Washington, in the United States [91] and Cardiff, in the United Kingdom [85,92-94]. In Cardiff, the high-incidence Crohn's disease "wards" are adjacent to the river in a pattern exactly downwind of the prevailing wind pattern, in contrast to ulcerative colitis cases that are spread throughout the city's wards [94-96]. The author believes that the MAP organism is concentrated in the aerosolized water bubbles, and it is this concentration of MAP bacteria to large numbers by the aerosolization process [97] that results in Crohn's disease rather than ulcerative colitis in infected patients.

The second route of MAP transmission to humans is through contaminated milk. Despite the concerted study of the possible transmission of MAP to humans from pasteurized milk $[98,99]$, the reported clusters of Crohn's disease suggest that it is unpasteurized or raw milk or milk products that carry the greater risk of infection. The author believes that the potentially large numbers of MAP in raw milk [21] and cheese [87] are the cause of the associated clusters of Crohn's disease; whereas the logarithmically smaller number of MAP organisms [100] in pasteurized milk [101] might trigger ulcerative colitis [102,103].
Finally, the literature suggests that MAP in milk is more invasive than MAP in water, because of the organism's passage through mammary gland epithelial cells and because of the hyperosmolar nature of milk [104]. The author speculates that the association between sugary cereals and an increased risk of Crohn's disease [105-107] and ulcerative colitis [108,109] may be a result of the increase in osmolarity of the milk caused by the sugar in the cereal, and decreasing the osmolarity of fluid in the digestive tract by carbohydrate-restricted diets $[110,111]$ may be the cause of their reported efficacy in treating both Crohn's disease and ulcerative colitis.

Crohn's disease and ulcerative colitis are not genetic diseases, but genetic polymorphisms related to the processing of intracellular bacteria, and specifically mycobacteria increase the risk of developing Crohn's disease rather than ulcerative colitis, when infected with MAP

Previous authors have suggested that ulcerative colitis and Crohn's disease have the same etiology, with Crohn's disease patients having more of the predisposing genes than ulcerative colitis patients:

Crohn's disease and ulcerative colitis may be the same disease with similar causes and with a quantitatively related genetic basis. Crohn's disease would be the result in people with a large concentration of genes, while fewer of the relevant genes would result in ulcerative colitis [112].

The accumulation of genetic polymorphisms associated with an increased risk of developing Crohn's disease as compared to ulcerative colitis supports this contention. The NOD2/CARD15 protein is an intracellular pattern recognition receptor that appears to not only recognize intracellular bacteria in general, but bacteria from the genus Mycobacteriae, including M. leprae [113,114] and MAP [115]. The ATG16L1 and IRGM proteins are involved in the process of autophagy, which is one of the ways cells process and eliminate intracellular bacteria [116]. The NRAMP (natural resistance associated macrophage protein) 1 gene [117] is associated with an increased risk of developing Johne's disease in sheep [118] as well as Crohn's disease [117], leprosy [119] and pulmonary MAC infections [120]. The NRAMP protein is expressed in reticuloendothelial cells [121], a possible location of the MAP organism in humans with Crohn's disease [122]. Individuals with one or more of these genetic polymorphisms, all of which make it slightly more difficult for individuals to process intracellular bacteria, have a slighter greater chance of developing Crohn's disease rather than ulcerative colitis, when infected with MAP. 
Individuals with these genetic polymorphisms do not, however, develop Crohn's or ulcerative colitis in any significant numbers. Infection with MAP causes Crohn's disease and ulcerative colitis independently of having these polymorphisms. "In other words, regardless of whether you carry the mutant allele or not, $M$. avium paratuberculosis infection has the same tendency to produce CD" [123]. Depending on the country and region, these genetic polymorphisms are not associated with Crohn's disease $[68,124]$.

The influence of sex: boys develop Crohn's disease more easily than girls, while men develop ulcerative colitis and women develop Crohn's disease, when infected with MAP It is commonly known that infant males are more prone to infectious diseases than infant females, probably due to weaker immune systems [125]. This weaker immune response might cause boys to develop Crohn's disease more often than ulcerative colitis [67,126-128] when infected with MAP, because they probably have a weaker immune response to the MAP organism. It has been postulated that Crohn's disease is not an autoimmune disease, a disease of excessive or over reactive immunity, but an immune deficiency disease [129]. Individuals with Crohn's disease have a less active response to the MAP organism, in contrast with individuals with ulcerative colitis, who have a more active response, as proposed above.

In contrast to children, adult females seem slightly but consistently more likely to develop Crohn's disease $[64,130]$ and adult males to develop ulcerative colitis when infected with MAP. While purely speculative, this difference might be due to the differing effects of testosterone [131] versus estrogen [132] on blood and lymphatic vessels, to the greater effects of smoking on females than males [133], or to the increase in oral contraceptive use, with its known vascular complications [134].

\section{Smoking increases the risk of both ulcerative colitis and Crohn's disease, but nicotine has different effects on colonic versus small bowel inflammation}

There are two commonly accepted beliefs about the relationship between smoking and Crohn's disease and ulcerative colitis: smoking increases the risk of Crohn's disease but protects an individual from developing ulcerative colitis, and smoking increases the severity of Crohn's disease, but decreases the severity of ulcerative colitis. If ulcerative colitis and Crohn's disease are both caused by MAP, how can these apparently dichotomous effects be explained? An excellent review article by Lakatos and colleagues [135] helps elucidate the reasons for the different effects of smoking on these diseases.
First, in children, smoking increases the risk of developing both ulcerative colitis and Crohn's disease. In a study of inflammatory bowel disease in Kentucky children [126], children who started smoking before 10 years of age were 7 times more likely to develop ulcerative colitis than nonsmokers, and over 3 times more likely to develop Crohn's disease than nonsmokers. If they started smoking before age 15, they were over three times more likely to develop both diseases. Smoking increased the risk of developing both Crohn's disease and ulcerative colitis, and in this one study increased the risk of ulcerative colitis (7 times greater risk) more than it increased the risk of Crohn's disease ('only' 3 times greater risk).

Secondly, the literature commonly cites the statistic that ulcerative colitis occurs in nonsmokers and exsmokers, but again a careful examination reveals that smoking does not protect someone from developing ulcerative colitis; it causes them to develop Crohn's disease instead. Bridger and colleagues [136] demonstrated that in siblings, smokers develop Crohn's disease while nonsmokers develop ulcerative colitis. They write:

We have shown...that in some cases smoking can probably displace the phenotype of chronic IBD from UC to CD...The explanation of the apparent "protective" effect of smoking on sporadic UC may be that the form of IBD that develops in a proportion of smokers is not UC but CD [136].

Not only does smoking predispose a MAP-infected individual to develop Crohn's disease rather than ulcerative colitis, it favors the development of small bowel disease [137], due to the effect of nicotine on reducing colonic inflammation as discussed below.

The idea that smoking predisposes an individual infected with MAP to develop Crohn's disease rather than ulcerative colitis is supported by the high prevalence of ulcerative colitis in members of the Mormon Church, "where smoking is strongly discouraged" [135]. In a study of Mormons in Britain and Ireland, ulcerative colitis was five times more common in Mormons than in the general population [138] while the prevalence of Crohn's disease was the same. In comparative studies of Hindus and Muslims in the United Kingdom [68,139-141], Hindus (more likely to be nonsmokers) had high rates of ulcerative colitis compared to Muslims (more likely to be smokers); not smoking switched the phenotype from Crohn's disease to ulcerative colitis. The lack of smoking did not protect nonsmoking populations from developing ulcerative colitis but instead caused them to have higher rates of ulcerative colitis compared to populations who smoked, keeping the 
overall prevalence of IBD the same but inverting the usual ulcerative colitis/Crohn's disease ratio.

But smokers with ulcerative colitis do have a more benign clinical course than nonsmokers. If MAP causes ulcerative colitis, what in the smoke is good for ulcerative colitis? It is the nicotine in the smoke that helps both colonic Crohn's disease and ulcerative colitis. First, nicotine reduces tone and muscular activity in the colon; it slows the colon down [142]. Secondly, nicotine increases small bowel inflammation but decreases colonic inflammation $[143,144]$. Transdermal nicotine patches help both ulcerative colitis patients and patients with colonic Crohn's disease [145].

So the superficial paradox of the effects of smoking on Crohn's disease and ulcerative colitis is rather easily explained. Smoking increases the risk of both diseases, and increases the risk that the clinical expression of MAP infection will be Crohn's disease rather than ulcerative colitis.

\section{Conclusion: hope for the prevention and cure of the no longer idiopathic inflammatory bowel diseases}

It is likely that MAP is the cause of a range of human gastrointestinal diseases including irritable bowel syndrome [146,147] as well as ulcerative colitis and Crohn's disease. MAP has also been investigated in the pathogenesis of other so-called autoimmune diseases including sarcoidosis $[148,149]$, type- 1 diabetes [150-152] and Hashimoto's thyroiditis [153]. If we accept that both ulcerative colitis and Crohn's disease are caused by a specific infectious microorganism, MAP, a long overdue transformation will take place in the prevention and treatment of these diseases. A rapid, focused effort to determine and implement the most efficacious treatments of already infected individuals [110,111,154-158], and methods of preventing initial infection by vaccination [159] and the effective removal of MAP organisms from drinking water [160] will become top priorities. We can end the "public health tragedy" [161] of Crohn's disease, and ulcerative colitis, in our lifetimes.

Dedicated to Cyrus E. Rubin, M.D.

\footnotetext{
Acknowledgements and Funding

My research would not be possible without the assistance of Gail Leong, Sandy Keno and Dr. Dodie Ruzicki at the Sacred Heart Medical Center Health Sciences Library in Spokane, Washington, as well as the other libraries that participate in the FreeShare library group within the DOCLINE National Network of Libraries of Medicine.

No funding was received for the preparation of this commentary.
}

\section{Competing interests}

The author declares that no competing interests exist.

Received: 9 December 2010 Accepted: 17 December 2010 Published: 17 December 2010

\section{Referencesz}

1. Packey CD, Sartor RB: Commensal bacteria, traditional and opportunistic pathogens, dysbiosis and bacterial killing in inflammatory bowel diseases. Curr Opin Infect Dis 2009, 22:292-301.

2. Packey CD, Sartor RB: Interplay of commensal and pathogenic bacteria, genetic mutations, and immunoregulatory defects in the pathogenesis of inflammatory bowel diseases. J Intern Med 2008, 263:597-606.

3. McGuckin MA, Eri R, Simms LA, Florin TH, Radford-Smith G: Intestinal barrier dysfunction in inflammatory bowel diseases. Inflamm Bowel Dis 2009, 15:100-113.

4. Fiocchi C: Susceptibility genes and overall pathogenesis of inflammatory bowel disease: where do we stand? Dig Dis 2009, 27:226-235.

5. Behr MA, Kapur V: The evidence for Mycobacterium paratuberculosis in Crohn's disease. Curr Opin Gastroenterol 2008, 24:17-21.

6. Chiodini RJ: Crohn's disease and the mycobacterioses: a review and comparison of two disease entities. Clin Microbiol Rev 1989, 2:90-117.

7. Hermon-Taylor J, Bull TJ, Sheridan JM, Cheng J, Stellakis ML, Sumar N: Causation of Crohn's disease by Mycobacterium avium subspecies paratuberculosis. Can J Gastroenterol 2000, 14:521-539.

8. Greenstein RJ: Is Crohn's disease caused by a mycobacterium? Comparisons with leprosy, tuberculosis, and Johne's disease. Lancet Infect Dis 2003, 3:507-514.

9. Collins MT: Paratuberculosis: review of present knowledge. Acta Vet Scand 2003, 44:217-221.

10. Harris NB, Barletta RG: Mycobacterium avium subsp. paratuberculosis in Veterinary Medicine. Clin Microbiol Rev 2001, 14:489-512.

11. Clarke CJ: The pathology and pathogenesis of paratuberculosis in ruminants and other species. J Comp Pathol 1997, 116:217-261.

12. Buergelt CD, Hall C, McEntee K, Duncan JR: Pathological evaluation of paratuberculosis in naturally infected cattle. Vet Pathol 1978, 15:196-207.

13. Sato $H$, Nakamatsu M, Fujimoto $Y$ : The pathological study of paratuberculosis in goats, centered around the formation of remote lesions. Jpn J Vet Res 1968, 16:103-119.

14. Perez V, Garcia Marin JF, Badiola JJ: Description and classification of different types of lesion associated with natural paratuberculosis infection in sheep. J Comp Pathol 1996, 114:107-122.

15. Glanemann B, Schonenbrucher H, Bridger N, Abdulmawjood A, Neiger R, Bulte M: Detection of Mycobacterium avium subspecies paratuberculosis-specific DNA by PCR in intestinal biopsies of dogs. J Vet Intern Med 2008, 22:1090-1094.

16. Jorgensen JB: Paratuberculosis in pigs. Experimental infection by oral administration of Mycobacterium paratuberculosis. Acta Vet Scand 1969, 10:275-287.

17. McClure HM, Chiodini RJ, Anderson DC, Swenson RB, Thayer WR, Coutu JA: Mycobacterium paratuberculosis infection in a colony of stumptail macaques (Macaca arctoides). J Infect Dis 1987, 155:1011-1019.

18. Tamboli C: A hypothesis for explaining the geographical distribution of Crohn's disease. The Canadian Journal of Gastroenterology 1996, 10:173-177.

19. Sherris JC, Ryan KJ: Medical microbiology: an introduction to infectious diseases New York: Elsevier; 1984.

20. Van Kruiningen HJ, Freda BJ: A clustering of Crohn's disease in Mankato, Minnesota. Inflamm Bowel Dis 2001, 7:27-33

21. Van Kruiningen HJ, Colombel JF, Cartun RW, Whitlock RH, Koopmans M, Kangro HO, Hoogkamp-Korstanje JA, Lecomte-Houcke M, Devred M, Paris JC, et al: An in-depth study of Crohn's disease in two French families. Gastroenterology 1993, 104:351-360.

22. Dorn SD, Abad JF, Panagopoulos G, Korelitz Bl: Clinical characteristics of familial versus sporadic Crohn's disease using the Vienna Classification. Inflamm Bowel Dis 2004, 10:201-206.

23. Carbonnel F, Macaigne G, Beaugerie L, Gendre JP, Cosnes J: Crohn's disease severity in familial and sporadic cases. Gut 1999, 44:91-95.

24. Henriksen M, Jahnsen J, Lygren I, Vatn MH, Moum B: Are there any differences in phenotype or disease course between familial and sporadic cases of inflammatory bowel disease? Results of a populationbased follow-up study. Am J Gastroenterol 2007, 102:1955-1963.

25. Lee JC, Lennard-Jones JE: Inflammatory bowel disease in 67 families each with three or more affected first-degree relatives. Gastroenterology 1996, 111:587-596.

26. White $\mathrm{CL}$, Hamilton SR, Diamond MP, Cameron JL: Crohn's disease and ulcerative colitis in the same patient. Gut 1983, 24:857-862. 
27. Chen Gl, Saibil F, Morava-Protzner I: Two for one: coexisting ulcerative colitis and Crohn's disease. Canadian journal of gastroenterology = Journal canadien de gastroenterologie 2002, 16:29-34.

28. Dwarakanath AD, Nash J, Rhodes JM: 'Conversion' from ulcerative colitis to Crohn's disease associated with corticosteroid treatment. Gut 1994, 35:1141-1144

29. Jones BJ, Gould SR, Pollock DJ: Coexistent ulcerative colitis and Crohn's disease. Postgrad Med J 1985, 61:647-649.

30. Naom I, Lee J, Ford D, Bowman SJ, Lanchbury JS, Haris I, Hodgson SV, Easton D, Lennard-Jones J, Mathew CG: Analysis of the contribution of HLA genes to genetic predisposition in inflammatory bowel disease. Am J Hum Genet 1996, 59:226-233.

31. Orholm M, Munkholm P, Langholz E, Nielsen $\mathrm{OH}$, Sorensen TI, Binder V: Familial occurrence of inflammatory bowel disease. N Engl J Med 1991, 324:84-88.

32. Monsen U, Bernell O, Johansson C, Hellers G: Prevalence of inflammatory bowel disease among relatives of patients with Crohn's disease. Scand J Gastroenterol 1991, 26:302-306.

33. Satsangi J, Grootscholten C, Holt H, Jewell DP: Clinical patterns of familial inflammatory bowel disease. Gut 1996, 38:738-741.

34. Lashner BA, Evans AA, Kirsner JB, Hanauer SB: Prevalence and incidence of inflammatory bowel disease in family members. Gastroenterology 1986, 91:1396-1400.

35. Singh K, Saunders $J$, Foley RJ: Inflammatory bowel disease in married couples. Gut 1995, 37:158.

36. Rhodes JM, Marshall T, Hamer JD, Allan RN: Crohn's disease in two married couples. Gut 1985, 26:1086-1087.

37. Holmes GK, Painter NS: Crohn's disease in married couples. Gut 1986, 27:350.

38. Comes MC, Gower-Rousseau C, Colombel JF, Belaiche J, Van Kruiningen HJ, Nuttens MC, Cortot A: Inflammatory bowel disease in married couples: 10 cases in Nord Pas de Calais region of France and Liege county of Belgium. Gut 1994, 35:1316-1318.

39. Laharie D, Debeugny S, Peeters M, Van Gossum A, Gower-Rousseau C, Belaiche J, Fiasse R, Dupas JL, Lerebours E, Piotte S, et al: Inflammatory bowel disease in spouses and their offspring. Gastroenterology 2001, 120:816-819.

40. Bennett RA, Rubin PH, Present DH: Frequency of inflammatory bowel disease in offspring of couples both presenting with inflammatory bowel disease. Gastroenterology 1991, 100:1638-1643.

41. Batty GM, Wilkins WE, Morris JS: Ulcerative colitis in a husband and wife. Gut 1994, 35:562-563.

42. Aisenberg J, Janowitz HD: Cluster of inflammatory bowel disease in three close college friends? J Clin Gastroenterol 1993, 17:18-20.

43. Sonnenberg A: Geographic variation in the incidence of and mortality from inflammatory bowel disease. Dis Colon Rectum 1986, 29:854-861.

44. Mendeloff Al: The epidemiology of inflammatory bowel disease. Clin Gastroenterol 1980, 9:259-270

45. Shivananda S, Hordijk ML, Pena AS, Mayberry JF: Inflammatory bowel disease: one condition or two? Digestion 1987, 38:187-192

46. Uzoigwe JC, Khaitsa ML, Gibbs PS: Epidemiological evidence for Mycobacterium avium subspecies paratuberculosis as a cause of Crohn's disease. Epidemiol Infect 2007, 135:1057-1068.

47. Feller M, Huwiler K, Stephan R, Altpeter E, Shang A, Furrer H, Pfyffer GE, Jemmi T, Baumgartner A, Egger M: Mycobacterium avium subspecies paratuberculosis and Crohn's disease: a systematic review and metaanalysis. The Lancet infectious diseases 2007, 7:607-613.

48. Abubakar I, Myhill D, Aliyu SH, Hunter PR: Detection of Mycobacterium avium subspecies paratuberculosis from patients with Crohn's disease using nucleic acid-based techniques: a systematic review and metaanalysis. Inflammatory bowel diseases 2008, 14:401-410.

49. Frank DN: Mycobacterium avium subspecies paratuberculosis and Crohn's disease. The Lancet infectious diseases 2008, 8:345-346, author reply 345

50. Sudre $P$, ten Dam G, Kochi A: Tuberculosis: a global overview of the situation today. Bull World Health Organ 1992, 70:149-159.

51. Bernstein CN, Blanchard JF, Rawsthorne P, Collins MT: Population-based case control study of seroprevalence of Mycobacterium paratuberculosis in patients with Crohn's disease and ulcerative colitis. J Clin Microbiol 2004, 42:1129-1135.

52. Naser SA, Hulten K, Shafran I, Graham DY, El-Zaatari FA: Specific seroreactivity of Crohn's disease patients against p35 and p36 antigens of M. avium subsp. paratuberculosis. Vet Microbiol 2000, 77:497-504.
53. Polymeros D, Bogdanos DP, Day R, Arioli D, Vergani D, Forbes A: Does cross-reactivity between mycobacterium avium paratuberculosis and human intestinal antigens characterize Crohn's disease? Gastroenterology 2006, 131:85-96

54. Murray A, Oliaro J, Schlup MM, Chadwick VS: Mycobacterium paratuberculosis and inflammatory bowel disease: frequency distribution in serial colonoscopic biopsies using the polymerase chain reaction. Microbios 1995, 83:217-228

55. Autschbach F, Eisold S, Hinz U, Zinser S, Linnebacher M, Giese T, Loffler T, Buchler MW, Schmidt J: High prevalence of Mycobacterium avium subspecies paratuberculosis IS900 DNA in gut tissues from individuals with Crohn's disease. Gut 2005, 54:944-949.

56. Sanderson JD, Moss MT, Tizard ML, Hermon-Taylor J: Mycobacterium paratuberculosis DNA in Crohn's disease tissue. Gut 1992, 33:890-896.

57. Dell'Isola B, Poyart C, Goulet O, Mougenot JF, Sadoun-Journo E, Brousse N, Schmitz J, Ricour C, Berche P: Detection of Mycobacterium paratuberculosis by polymerase chain reaction in children with Crohn's disease. The Journal of infectious diseases 1994, 169:449-451.

58. Romero C, Hamdi A, Valentine JF, Naser SA: Evaluation of surgical tissue from patients with Crohn's disease for the presence of Mycobacterium avium subspecies paratuberculosis DNA by in situ hybridization and nested polymerase chain reaction. Inflammatory bowel diseases 2005, 11:116-125.

59. Naser SA, Ghobrial G, Romero C, Valentine JF: Culture of Mycobacterium avium subspecies paratuberculosis from the blood of patients with Crohn's disease. Lancet 2004, 364:1039-1044.

60. Jeyanathan M, Boutros-Tadros O, Radhi J, Semret M, Bitton A, Behr MA: Visualization of Mycobacterium avium in Crohn's tissue by oil-immersion microscopy. Microbes Infect 2007, 9:1567-1573.

61. Hulten K, El-Zimaity HM, Karttunen TJ, Almashhrawi A, Schwartz MR Graham DY, El-Zaatari FA: Detection of Mycobacterium avium subspecies paratuberculosis in Crohn's diseased tissues by in situ hybridization. Am J Gastroenterol 2001, 96:1529-1535.

62. Gelfand MD, Krone CL: Inflammatory bowel disease in a family. Observations related to pathogenesis. Ann Intern Med 1970, 72:903-907.

63. Sinclair TS, Brunt PW, Mowat NA: Nonspecific proctocolitis in northeastern Scotland: a community study. Gastroenterology 1983, 85:1-11.

64. Kyle J: An epidemiological study of Crohn's disease in Northeast Scotland. Gastroenterology 1971, 61:826-833.

65. Kyle J: Crohn's disease in the northeastern and northern Isles of Scotland: an epidemiological review. Gastroenterology 1992, 103:392-399.

66. Shivananda S, Pena AS, Nap M, Weterman IT, Mayberry JF, Ruitenberg EJ, Hoedemaeker PJ: Epidemiology of Crohn's disease in Regio Leiden, The Netherlands. A population study from 1979 to 1983. Gastroenterology 1987, 93:966-974.

67. Kugathasan S, Judd RH, Hoffmann RG, Heikenen J, Telega G, Khan F Weisdorf-Schindele S, San Pablo W Jr, Perrault J, Park R, et al: Epidemiologic and clinical characteristics of children with newly diagnosed inflammatory bowel disease in Wisconsin: a statewide population-based study. J Pediatr 2003, 143:525-531.

68. Yang SK, Loftus EV Jr, Sandborn WJ: Epidemiology of inflammatory bowel disease in Asia. Inflammatory bowel diseases 2001, 7:260-270.

69. Loftus EV Jr: Clinical epidemiology of inflammatory bowel disease: Incidence, prevalence, and environmental influences. Gastroenterology 2004, 126:1504-1517

70. Probert CS, Jayanthi V, Rampton DS, Mayberry JF: Epidemiology of inflammatory bowel disease in different ethnic and religious groups: limitations and aetiological clues. Int J Colorectal Dis 1996, 11:25-28.

71. Windsor PA, Whittington RJ: Evidence for age susceptibility of cattle to Johne's disease. Vet J 2010, 184:37-44.

72. Jeyanathan M, Alexander DC, Turenne CY, Girard C, Behr MA: Evaluation of in situ methods used to detect Mycobacterium avium subsp. paratuberculosis in samples from patients with Crohn's disease. J Clin Microbiol 2006, 44:2942-2950.

73. Smith AM, Rahman FZ, Hayee B, Graham SJ, Marks DJ, Sewell GW, Palmer CD, Wilde J, Foxwell BM, Gloger IS, et al: Disordered macrophage cytokine secretion underlies impaired acute inflammation and bacterial clearance in Crohn's disease. J Exp Med 2009, 206:1883-1897.

74. Turenne CY, Wallace R Jr, Behr MA: Mycobacterium avium in the postgenomic era. Clinical microbiology reviews 2007, 20:205-229. 
75. Hilborn ED, Covert TC, Yakrus MA, Harris SI, Donnelly SF, Rice EW, Toney S, Bailey SA, Stelma GN Jr: Persistence of nontuberculous mycobacteria in a drinking water system after addition of filtration treatment. Applied and environmental microbiology 2006, 72:5864-5869.

76. Falkinham JO: Factors influencing the chlorine susceptibility of Mycobacterium avium, Mycobacterium intracellulare, and Mycobacterium scrofulaceum. Applied and environmental microbiology 2003, 69:5685-5689.

77. Falkinham JO, Norton CD, LeChevallier MW: Factors influencing numbers of Mycobacterium avium, Mycobacterium intracellulare, and other Mycobacteria in drinking water distribution systems. Applied and environmental microbiology 2001, 67:1225-1231.

78. Vaerewijck MJ, Huys G, Palomino JC, Swings J, Portaels F: Mycobacteria in drinking water distribution systems: ecology and significance for human health. FEMS Microbiol Rev 2005, 29:911-934.

79. Tatchou-Nyamsi-Konig JA, Dailloux M, Block JC: Survival of Mycobacterium avium attached to polyethylene terephtalate (PET) water bottles. J Appl Microbiol 2009, 106:825-832.

80. Glover NHA, Aronson T, Froman S, Berlin OGW, Dominguez P, Kunkel KA, Overturf G, Stelma G Jr, Smith C, Yakrus M: The isolation and identification of Mycobacterium avium complex (MAC) recovered from Los Angeles potable water, a possible source of infection in AIDS patients. Internation Journal of Environmental Health Research 1994, 4:63-72

81. Beumer A, King D, Donohue M, Mistry J, Covert T, Pfaller S: Detection of Mycobacterium avium subsp. paratuberculosis in drinking water and biofilms by quantitative PCR. Applied and environmental microbiology 2010, 76:7367-7370.

82. von Reyn CF, Waddell RD, Eaton T, Arbeit RD, Maslow JN, Barber TW, Brindle RJ, Gilks CF, Lumio J, Lahdevirta J, et al: Isolation of Mycobacterium avium complex from water in the United States, Finland, Zaire, and Kenya. J Clin Microbiol 1993, 31:3227-3230.

83. Ehlin AG, Montgomery SM, Ekbom A, Pounder RE, Wakefield AJ: Prevalence of gastrointestinal diseases in two British national birth cohorts. Gut 2003, 52:1117-1121.

84. Hassan K, Cowan FJ, Jenkins HR: The incidence of childhood inflammatory bowel disease in Wales. Eur J Pediatr 2000, 159:261-263.

85. Yapp TR, Stenson R, Thomas GA, Lawrie BW, Williams GT, Hawthorne AB: Crohn's disease incidence in Cardiff from 1930: an update for 1991-1995. Eur J Gastroenterol Hepatol 2000, 12:907-911.

86. Miller RC, Larsen E: Regional enteritis in early infancy. Am J Dis Child 1971 122:301-311.

87. Van Kruiningen $\mathrm{HJ}$, Joossens $M$, Vermeire $S$, Joossens $S$, Debeugny $S$, Gower-Rousseau C, Cortot A, Colombel JF, Rutgeerts P, Vlietinck R: Environmental factors in familial Crohn's disease in Belgium. Inflammatory bowel diseases 2005, 11:360-365.

88. Pierce ES: Possible transmission of Mycobacterium avium subspecies paratuberculosis through potable water: lessons from an urban cluster of Crohn's disease. Gut Pathog 2009, 1:17

89. Allan RN, Pease P, Ibbotson JP: Clustering of Crohn's disease in a Cotswold village. Q J Med 1986, 59:473-478.

90. Jones PH, Farver TB, Beaman B, Cetinkaya B, Morgan KL: Crohn's disease in people exposed to clinical cases of bovine paratuberculosis. Epidemiol Infect 2006, 134:49-56.

91. Nunes GC, Ahlquist RE Jr: Increasing incidence of Crohn's disease. Am J Surg 1983, 145:578-581.

92. Thomas GA, Millar-Jones D, Rhodes J, Roberts GM, Williams GT, Mayberry JF: Incidence of Crohn's disease in Cardiff over 60 years: 1986-1990 an update. Eur J Gastroenterol Hepatol 1995, 7:401-405.

93. Gunesh S, Thomas GA, Williams GT, Roberts A, Hawthorne AB: The incidence of Crohn's disease in Cardiff over the last 75 years: an update for 1996-2005. Aliment Pharmacol Ther 2008, 27:211-219.

94. Pickup RW, Rhodes G, Arnott S, Sidi-Boumedine K, Bull TJ, Weightman A, Hurley M, Hermon-Taylor J: Mycobacterium avium subsp. paratuberculosis in the catchment area and water of the River Taff in South Wales, United Kingdom, and its potential relationship to clustering of Crohn's disease cases in the city of Cardiff. Applied and environmental microbiology 2005, 71:2130-2139.

95. Mayberry JF, Hitchens RA: Distribution of Crohn's disease in Cardiff. SoC Sci Med 1978, 12:137-138

96. Mayberry JF: Recent epidemiology of ulcerative colitis and Crohn's disease. Int J Colorectal Dis 1989, 4:59-66.
97. Blanchard DC, Syzdek LD: Water-to-Air Transfer and Enrichment of Bacteria in Drops from Bursting Bubbles. Applied and environmental microbiology 1982, 43:1001-1005.

98. Grant IR: Mycobacterium paratuberculosis and milk. Acta veterinaria Scandinavica 2003, 44:261-266.

99. Lund BM, Gould GW, Rampling AM: Pasteurization of milk and the heat resistance of Mycobacterium avium subsp. paratuberculosis: a critical review of the data. Int J Food Microbiol 2002, 77:135-145.

100. Gao A, Mutharia L, Chen S, Rahn K, Odumeru J: Effect of pasteurization on survival of Mycobacterium paratuberculosis in milk. J Dairy Sci 2002, 85:3198-3205.

101. Ellingson $J$, Anderson $J$, Koziczkowski JJ, Radcliff RP, Sloan SJ, Allen SE, Sullivan NM: Detection of viable Mycobacterium avium subsp. paratuberculosis in retail pasteurized whole milk by two culture methods and PCR. J Food Prot 2005, 68:966-972.

102. Truelove SC: Ulcerative colitis provoked by milk. Br Med J 1961, 1:154-160.

103. Glassman MS, Newman LJ, Berezin S, Gryboski JD: Cow's milk protein sensitivity during infancy in patients with inflammatory bowel disease. Am J Gastroenterol 1990, 85:838-840.

104. Patel D, Danelishvili L, Yamazaki Y, Alonso M, Paustian ML, Bannantine JP, Meunier-Goddik L, Bermudez LE: The ability of Mycobacterium avium subsp. paratuberculosis to enter bovine epithelial cells is influenced by preexposure to a hyperosmolar environment and intracellular passage in bovine mammary epithelial cells. Infect Immun 2006, 74:2849-2855.

105. Chasing the cause of Crohn's disease. Br Med J 1977, 1:929-930.

106. Mayberry JF, Rhodes J, Newcombe RG: Breakfast and dietary aspects of Crohn's disease. Br Med J 1978, 2:1401.

107. Thornton JR, Emmett PM, Heaton KW: Diet and Crohn's disease: characteristics of the pre-illness diet. Br Med J 1979, 2:762-764.

108. Reif S, Klein I, Lubin F, Farbstein M, Hallak A, Gilat T: Pre-illness dietary factors in inflammatory bowel disease. Gut 1997, 40:754-760.

109. Tragnone A, Valpiani D, Miglio F, Elmi G, Bazzocchi G, Pipitone E, Lanfranchi GA: Dietary habits as risk factors for inflammatory bowel disease. Eur J Gastroenterol Hepatol 1995, 7:47-51.

110. Rashid T, Ebringer A, Tiwana $H$, Fielder M: Role of Klebsiella and collagens in Crohn's disease: a new prospect in the use of low-starch diet. Eur J Gastroenterol Hepatol 2009, 21:843-849.

111. E G: Breaking the Vicious Cycle: Intestinal Health through Diet Ontario: The Kirkton Press; 1994.

112. Lewkonia RM, McConnell RB: Progress report. Familial inflammatory bowel disease-heredity or environment? Gut 1976, 17:235-243.

113. Zhang FR, Huang W, Chen SM, Sun LD, Liu H, Li Y, Cui Y, Yan XX, Yang HT, Yang RD, et al: Genomewide association study of leprosy. N Engl J Med 2009, 361:2609-2618.

114. Schurr $E$, Gros P: A common genetic fingerprint in leprosy and Crohn's disease? N Engl J Med 2009, 361:2666-2668.

115. Ferwerda G, Kullberg BJ, de Jong DJ, Girardin SE, Langenberg DM, van Crevel R, Ottenhoff TH, Van der Meer JW, Netea MG: Mycobacterium paratuberculosis is recognized by Toll-like receptors and NOD2. J Leukoc Biol 2007, 82:1011-1018.

116. Lalande JD, Behr MA: Mycobacteria in Crohn's disease: how innate immune deficiency may result in chronic inflammation. Expert Rev Clin Immunol 2010, 6:633-641.

117. Hofmeister A, Neibergs HL, Pokorny RM, Galandiuk S: The natural resistance-associated macrophage protein gene is associated with Crohn's disease. Surgery 1997, 122:173-178, discussion 178-179.

118. Reddacliff $L A$, Beh $K$, McGregor $H$, Whittington RJ: A preliminary study of possible genetic influences on the susceptibility of sheep to Johne's disease. Aust Vet J 2005, 83:435-441.

119. Abel L, Sanchez FO, Oberti J, Thuc NV, Hoa LV, Lap VD, Skamene E, Lagrange PH, Schurr E: Susceptibility to leprosy is linked to the human NRAMP1 gene. The Journal of infectious diseases 1998, 177:133-145.

120. Tanaka G, Shojima J, Matsushita I, Nagai H, Kurashima A, Nakata K, Toyota E, Kobayashi N, Kudo K, Keicho N: Pulmonary Mycobacterium avium complex infection: association with NRAMP1 polymorphisms. Eur Respir J 2007, 30:90-96

121. Bellamy R: The natural resistance-associated macrophage protein and susceptibility to intracellular pathogens. Microbes Infect 1999, 1:23-27.

122. Pierce ES: Where are all the Mycobacterium avium subspecies paratuberculosis in patients with Crohn's disease? PLoS Pathog 2009, 5: e1000234 
123. Sieswerda LE, Bannatyne RM: Mapping the effects of genetic susceptibility and Mycobacterium avium subsp. paratuberculosis infection on Crohn's disease: strong but independent. J Clin Microbiol 2006, 44:1204-1205.

124. Ahuja V, Tandon RK: Inflammatory bowel disease in the Asia-Pacific area: a comparison with developed countries and regional differences. J Dig Dis 2010, 11:134-147.

125. Organization WH: Addressing sex and gender in epidemic-prone infectious diseases Geneva: WHO Press; 2007.

126. Mahid SS, Minor KS, Stromberg AJ, Galandiuk S: Active and passive smoking in childhood is related to the development of inflammatory bowel disease. Inflammatory bowel diseases 2007, 13:431-438.

127. Sawczenko A, Sandhu BK, Logan RF, Jenkins H, Taylor CJ, Mian S, Lynn R: Prospective survey of childhood inflammatory bowel disease in the British Isles. Lancet 2001, 357:1093-1094.

128. Bernstein CN, Blanchard JF, Rawsthorne P, Wajda A: Epidemiology of Crohn's disease and ulcerative colitis in a central Canadian province: a population-based study. Am J Epidemiol 1999, 149:916-924.

129. Marks DJ, Rahman FZ, Sewell GW, Segal AW: Crohn's disease: an immune deficiency state. Clin Rev Allergy Immunol 2010, 38:20-31.

130. Calkins BM, Mendeloff Al: Epidemiology of inflammatory bowel disease. Epidemiol Rev 1986, 8:60-91.

131. Littleton-Kearney M, Hurn PD: Testosterone as a modulator of vascular behavior. Biol Res Nurs 2004, 5:276-285.

132. Rogers PA, Donoghue JF, Walter LM, Girling JE: Endometrial angiogenesis, vascular maturation, and lymphangiogenesis. Reprod Sci 2009, 16:147-151.

133. Ashley MJ: Smoking and diseases of the gastrointestinal system: an epidemiological review with special reference to sex differences. Canadian journal of gastroenterology = Journal canadien de gastroenterologie 1997, 11:345-352.

134. Wakefield AJ, Sawyerr AM, Hudson M, Dhillon AP, Pounder RE: Smoking, the oral contraceptive pill, and Crohn's disease. Dig Dis Sci 1991, 36:1147-1150

135. Lakatos PL, Szamosi T, Lakatos L: Smoking in inflammatory bowel diseases: good, bad or ugly? World J Gastroenterol 2007, 13:6134-6139.

136. Bridger S, Lee JC, Bjarnason I, Jones JE, Macpherson AJ: In siblings with similar genetic susceptibility for inflammatory bowel disease, smokers tend to develop Crohn's disease and non-smokers develop ulcerative colitis. Gut 2002, 51:21-25.

137. Lindberg E, Jarnerot G, Huitfeldt B: Smoking in Crohn's disease: effect on localisation and clinical course. Gut 1992, 33:779-782.

138. Penny WJ, Penny E, Mayberry JF, Rhodes J: Prevalence of inflammatory bowel disease amongst Mormons in Britain and Ireland. Soc Sci Med 1985, 21:287-290.

139. Probert CS, Jayanthi V, Pinder D, Wicks AC, Mayberry JF: Epidemiological study of ulcerative proctocolitis in Indian migrants and the indigenous population of Leicestershire. Gut 1992, 33:687-693.

140. Jayanthi V, Probert CS, Pollock DJ, Baithun SI, Rampton DS, Mayberry JF: Low incidence of ulcerative colitis and proctitis in Bangladeshi migrants in Britain. Digestion 1992, 52:34-42.

141. Jayanthi V, Probert CS, Pinder D, Wicks AC, Mayberry JF: Epidemiology of Crohn's disease in Indian migrants and the indigenous population in Leicestershire. Q J Med 1992, 82:125-138.

142. Coulie B, Camilleri M, Bharucha AE, Sandborn WJ, Burton D: Colonic motility in chronic ulcerative proctosigmoiditis and the effects of nicotine on colonic motility in patients and healthy subjects. Aliment Pharmacol Ther 2001, 15:653-663.

143. Karban A, Eliakim R: Effect of smoking on inflammatory bowel disease: Is it disease or organ specific? World J Gastroenterol 2007, 13:2150-2152.

144. Eliakim R, Karmeli F, Cohen P, Heyman SN, Rachmilewitz D: Dual effect of chronic nicotine administration: augmentation of jejunitis and amelioration of colitis induced by iodoacetamide in rats. Int $\mathrm{J}$ Colorectal Dis 2001, 16:14-21

145. Ingram JR, Rhodes J, Evans BK, Thomas GA: Nicotine enemas for active Crohn's colitis: an open pilot study. Gastroenterol Res Pract 2008, 2008:237185.

146. Scanu AM, Bull TJ, Cannas S, Sanderson JD, Sechi LA, Dettori G, Zanetti S, Hermon-Taylor J: Mycobacterium avium subspecies paratuberculosis infection in cases of irritable bowel syndrome and comparison with Crohn's disease and Johne's disease: common neural and immune pathogenicities. J Clin Microbiol 2007, 45:3883-3890.
147. Olbe L: Concept of Crohn's disease being conditioned by four main components, and irritable bowel syndrome being an incomplete Crohn's disease. Scand J Gastroenterol 2008, 43:234-241.

148. el-Zaatari FA, Naser SA, Markesich DC, Kalter DC, Engstand L, Graham DY: Identification of Mycobacterium avium complex in sarcoidosis. J Clin Microbiol 1996, 34:2240-2245

149. Reid JD, Chiodini RJ: Serologic reactivity against Mycobacterium paratuberculosis antigens in patients with sarcoidosis. Sarcoidosis 1993, 10:32-35.

150. Sechi LA, Rosu V, Pacifico A, Fadda G, Ahmed N, Zanetti S: Humoral immune responses of type 1 diabetes patients to Mycobacterium avium subsp. paratuberculosis lend support to the infectious trigger hypothesis. Clin Vaccine Immunol 2008, 15:320-326.

151. Rosu V, Ahmed N, Paccagnini D, Gerlach G, Fadda G, Hasnain SE, Zanetti S, Sechi LA: Specific immunoassays confirm association of Mycobacterium avium Subsp. paratuberculosis with type-1 but not type-2 diabetes mellitus. PLoS One 2009, 4:e4386.

152. Paccagnini D, Sieswerda L, Rosu V, Masala S, Pacifico A, Gazouli M, Ikonomopoulos J, Ahmed N, Zanetti S, Sechi LA: Linking chronic infection and autoimmune diseases: Mycobacterium avium subspecies paratuberculosis, SLC11A1 polymorphisms and type-1 diabetes mellitus. PLoS One 2009, 4:e7109.

153. Sisto M, Cucci L, D'Amore M, Dow TC, Mitolo V, Lisi S: Proposing a relationship between Mycobacterium avium subspecies paratuberculosis infection and Hashimoto's thyroiditis. Scand J Infect Dis 2010, 42:787-790.

154. Feller M, Huwiler K, Schoepfer A, Shang A, Furrer H, Egger M: Long-term antibiotic treatment for Crohn's disease: systematic review and metaanalysis of placebo-controlled trials. Clin Infect Dis 2010, 50:473-480.

155. Click RE, Van Kampen CL: Short communication: progression of Johne's disease curtailed by a probiotic. J Dairy Sci 2009, 92:4846-4851.

156. Do VT, Baird BG, Kockler DR: Probiotics for maintaining remission of ulcerative colitis in adults. Ann Pharmacother 2010, 44:565-571.

157. Guandalini S: Update on the role of probiotics in the therapy of pediatric inflammatory bowel disease. Expert Rev Clin Immunol 2010, 6:47-54.

158. Wong SY, Grant IR, Friedman M, Elliott CT, Situ C: Antibacterial activities of naturally occurring compounds against Mycobacterium avium subsp. paratuberculosis. Applied and environmental microbiology 2008, 74:5986-5990.

159. Bull TJ, Gilbert SC, Sridhar S, Linedale R, Dierkes N, Sidi-Boumedine K, Hermon-Taylor J: A novel multi-antigen virally vectored vaccine against Mycobacterium avium subspecies paratuberculosis. PLoS One 2007, 2: e1229.

160. Hayes SL, Sivaganesan M, White KM, Pfaller SL: Assessing the effectiveness of low-pressure ultraviolet light for inactivating Mycobacterium avium complex (MAC) micro-organisms. Lett App/ Microbiol 2008, 47:386-392.

161. Hermon-Taylor J, Bull T: Crohn's disease caused by Mycobacterium avium subspecies paratuberculosis: a public health tragedy whose resolution is long overdue. J Med Microbiol 2002, 51:3-6.

doi:10.1186/1757-4749-2-21

Cite this article as: Pierce: Ulcerative colitis and Crohn's disease: is Mycobacterium avium subspecies paratuberculosis the common villain? Gut Pathogens 2010 2:21.

\section{Submit your next manuscript to BioMed Central and take full advantage of:}

- Convenient online submission

- Thorough peer review

- No space constraints or color figure charges

- Immediate publication on acceptance

- Inclusion in PubMed, CAS, Scopus and Google Scholar

- Research which is freely available for redistribution 